York 2ribune, says :- "Governor Anny, the indefatigable special Indian agent for this territory, has lately returned from a point north of the San Juan country, and reports that during his tour to reach the Utah Indians, his party found the Canon de Chelly in the great Sierras, which was explored for more than twenty miles. Among canons towering precipitously to the height of I, 000 to 2,000 feet, they found deserted ruins of Aztec cities, many of which bear the evidences of having been highly populous. In one of these canons, the rocky walls of which rose not less than 2,000 feet from the base, and whose summits on either hand inclined to each other, forming part of an arch, there were found high up, hewn out of the rocks, the mins of Aztec cities of great extent. In each of these rocky eyries there remainct in a state of good preservation a house built of stone, about twenty feet square, containing one bare and gloomy room, in the centre of which were traces of fire, and also a single human skeleton. The only solution of this enigma thus far advanced is that these solitary rooms were the altar places of the Aztec fires; that from some cause the people at a remote period were constrained to abandon their homes, but lelt one faithful sentinel in each instance to keep alive the flame which, according to the Indian traditions of these regions, was to light the way of Montezuma, their so long hoperl for Messiah, again to his people. A close examina. tion of many of the ruins proved that the builder must have been skilled in the manufacture and use of edged tools, masonry, and other mechanical arts." A good idea of these rocky canons or mountain gorges will he obtained by reference to the description and illustrations of the Cannons of the Sierra Nevala, given in NATURE, vol, i. p. 434

IN directing attention to the recent regulations with regard to scientific teaching in force at Vale College, in our present number, we alluded to the exploring party which left Yale College under the charge of Prof. Marsh. We are glad to announce that their endeavours have been crowned with great success. They spent three weeks examining the groology of the country between the north and south branches of the River Platte, and discovered in Northern Colorado an extensive tertiary deposit, abound ing in fossil remnins. The formation is identical with the "Mauvaises terres" cleposit of Dakota, and apparently forms the south-western border of some ancient fresh-water lake (see Nature, Vol. II., p. 385, "The Ancient Lakes of Western America"). These becls were traced to the north, and along the North I'latte River; several thousand specimens were collected, and among them a number of new species of tertiary mammals.

ARRANGEMENTS are being made to light the stations of Rawul Pindee in India with gas from the local deposits of petroleum, being one of the first examples of their utilisation.

FULLER details have now arrived of the great earthquake we reported as having occurred in Thibet in May, and which exiencled over a wide area of comtry.

Mr. Brovghton, the Government quinologist in India, has bren called upon to examine the bark of an indigenous Indian rree, Hymenodictyon excelsum, supposed to be a powerful febrifuge. He reports that it contains a bitter principle, identical with xsculin, and also found in the horse-chestnut tree, but of little therapeutic value.

TIIE experiments in growing Carolina rice in our great ricecountry of English Burmah are reported as having failed.

IT may be esteemed a benefit that we have a local press in India, which may collect for us more facts as to natural phenomena, but the acceptance of anything from such sources must be received with caution. New facts about snakes are in this class. The Vellore correspondent of the Madras Standard asserts on reliable information that a native woman near that torn lately gave birth to a child and a snake, and that another has produced twins, and a third child, which looked like a toy elephant. A very respectable and well-educated Mussulman lately reported the exhibition, we tlink at Benares, of a mermaid from Japan, which he accepted on the evidence of his own eyes and the statements of the highly respectable Mussulman showmen, and duly reported to the paper of which he is the correspondent.

$A$ Goon example of the value of agricultural shows and their influence on produce, is shown in India by the Vellore shows, which have now been held for twelve years. At the same time the results show the difficulty of organising cattle-shows there, and how it may be overcome. As is well known, the superstition about the sacred cow is strong in India, and the ryots can hardly be got to exhibit, and the first cows shown were scarcely worth a prize. Now the exhibition of the famous Vellore breed has reached 173 cows and heifers, and a great improvement is risible. It is suggested that the exhibition of Vellore bulls will also be attended with advantage. In India the greatest care is requisite in the most trivial undertakings in dealing with the superstitions of the natives.

Tre Cinchona cultivation has so well succeeded in the English hill settlement at Darjeeling, in the Himalayas, that last year 5 ,ooolbs. of bark was sent to London from Cinchona trees planted in 1862 on one plantation. Tea produced, in 1869 , I,319,743lbs. from 10,769 acres of hill land formerly said and reputed to be worthless, and unsuitcl to give a retum to Englishmen. We shall now hear of Indian bark as well as Peruvian, as we know Indian tea to hold its own against Chinese.

CONGRES has granted 30,000 dollars for the erection of a Government Winter Garden, either at New York or Washington, somewhat similar to that at Kew, but on a smaller scale. This will partake partly of the nature of an economic garden, in which useful plants can be raised and then disseminated far and wide throughout the States.

"THE Reign of Law," by the Duke of Argyll, which has been published so long in England, has at last been repulblished in America. It is amounced as the first American from the fifth London edition, published by C. Leat and Co., New York. We also hear of a Canadian reprint of P'rof. Huxley's " Lay Sermons."

THE cinchona trees are taking well in Jamaica. Experiments on the culture of American tobacco in Inclia are being made by the Maharajah of Burchwan in Midnapore and Cuttack. The last year's experiments with seeds from James River, Virginia were very successful.

Argentriferous galena has been discovered in the district of Beerbhoom, in India, by Mr. Ball, of the Geological Survey. The assay of some picked specimens gives roozs. of silver to the ton of lead, and it is considered there is a sufficient quantity of ore to justify working.

\section{ERUPTION OF THE VOLCANO TONGARIRO, NEW ZEALAND}

THROUGH the kindress of Dr. J. D. Hooker, we have received the following important and interesting account of the eruption of this volcano, together with drawings, from the pencil of Dr. Hector, of the most interesting features of the mountain itself, from which we are enabled to copy the accompanying woodcuts:-m

Dr. Hector announced, at the meeting of the Wellington Philosophical Society of New Zealand, held July i7th, that Tongariro, the only active volcano in the colony, 


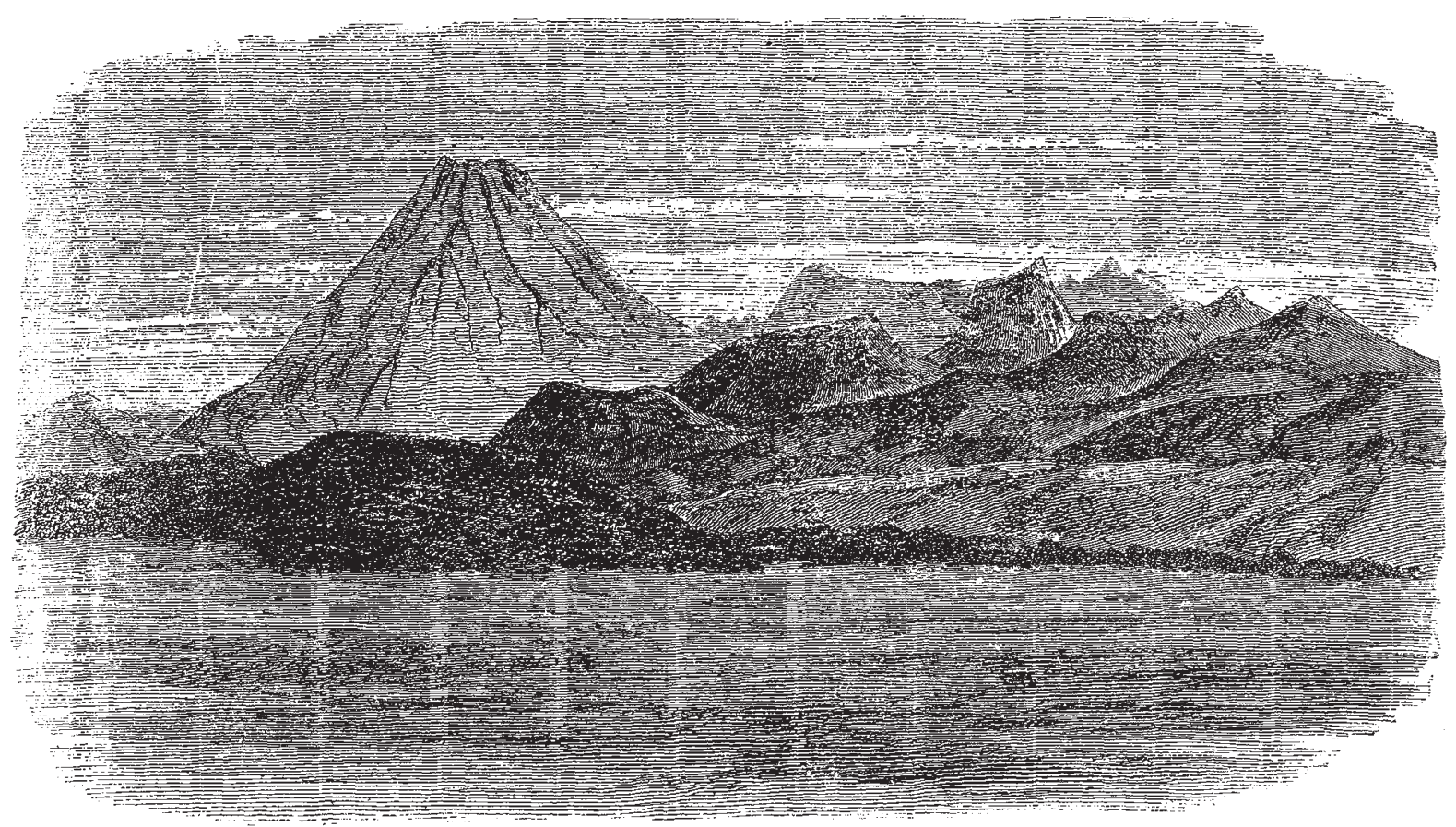

NGALR HOF CONE OE TONGARIRO, FRGA THE EAST

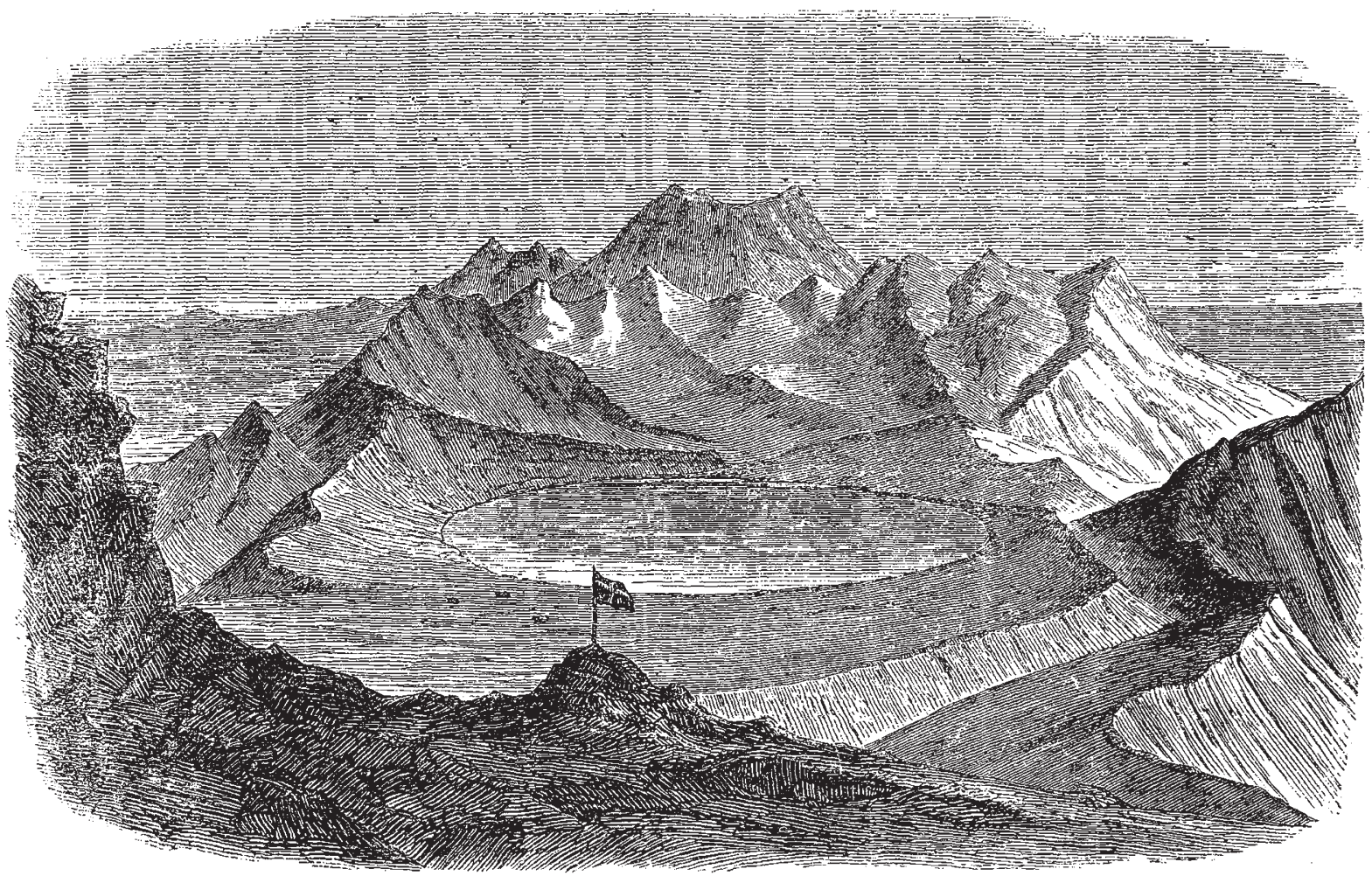

LAKE ON THE TOP OF TONGARIRO, LOOKING SOLTH OVEK NGAURUHOE AND RUAPEHU 
which is situated in the interior of the North Island, had burst into active eruption in the month of April last, and for the first time within the knowledge of the colonists, or even the traditions of the Maories, lava streams have been emitted. On the occasion of previous eruptions, the outbursts have consisted only of ashes and gaseous matters, the former having been spread over a district extending for upwards of thirty miles round the mountain. The volcano is 6,000 feet high, and consists of a group of irregular broken cones, and one very perfect cone, knowl to the natives as Ngauruboe. Jets of boiling water and steam continually issue from the north side of the mountain. At an altitude of 3,600 feet, and on the top of Tongariro proper, is a lake 300 yards across, the water of which is of an intense green colour. Ten miles to the south of Tongariro is the ancient trachyte cone of Ruapeht, which is the loftiest mountain in the North Island, having an altitude of 9,600 feet. It is a notable circumstance, that on the 5 th of April last, when electrical disturbances were so marked in Europe, and the hrilliant displays of Aurora Borealis were generally observed, the corresponding phenomena of the Aurora Australis were extremely well marked in the Southern Hemisphere, attended also by electrical disturbances of unusual character; and on the same evening a well-marked earthquake shock was experienced in the volcanic district of New Zealand, and shortly after the above eruption was reported. The country is very inaccessible at this season, but from the north end of Taupo Lake, where there is now a telegraph station, a distant view is obtained. On the Ioth July, the immense volumes of dense black smoke which are being emitted from Tongariro were plainly visible from the hills at Napier, as well as from parts of the surrounding plains. Loud reports were distinctly heard for the previous fortnight, like the boom of heavy artillery, or rather the noise caused by the falling of an immense body of matter, at intervals of five minutes or thereabout. These reports (which are very loud in the vicinity) are sometimes accompanied by a quiver of the earth, and in each case by a great up-burst of flame and red-hot masses like molten rock. A broad stream of red-hot lava is distinctly visible flowing down the side of the mountain in a wavy irregular mass; and in the night the flames issuing from the crater are described as forming a highly interesting and beautiful spectacle.

On the 18 th a surveyor reports that he observed, about I. 5 P.M., a sudden column of smoke come out of Tongariro (just as if a steamer was firing up), and soon after it seemed to change to white steam ; he stood on a hill about eighty miles distant, and could just see the top of Tongariro to the east of the shoulders of Ruapehu.

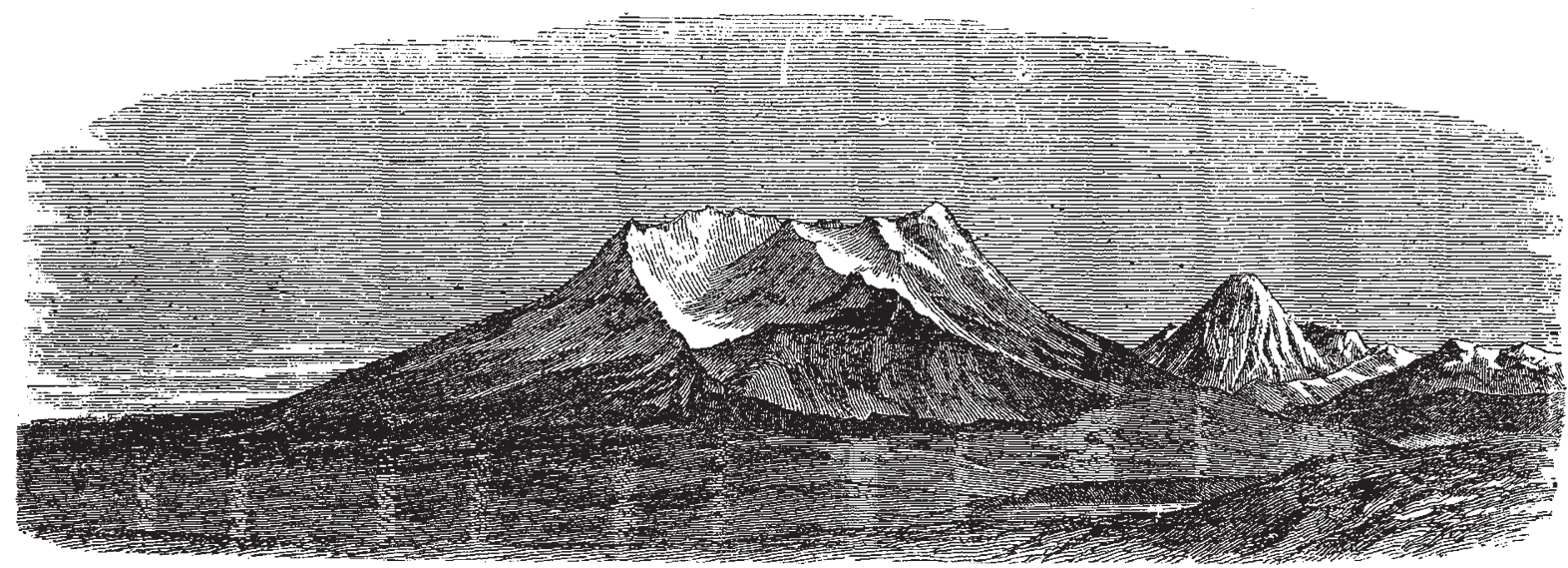

RUAPEHU AND TONGARIRO, FROM THE ONETAPU DESERT, ON THE SOETH-EAST SIDE AT THE SOURCES OF THE RANGITIKII KIVER

\section{THE BRITISH ASSOCIATION}

\section{SECTIONAL PROCEEDINGS}

Sfiction A.-Mathematical and Physical Science

The Radcliffe Observer (Rev. R. Main) communicated the Observations of Shooting Stars made at the Observatory durving the past year, from 1869 , August 19 , to $187 \mathrm{O}$, August $3 \mathrm{I}$.

Since the last report to the British Association, nearly 300 shooting stars have been observed by Mr. Luces at the Radcliffe Observatory, Oxford, distributed as follows :--

27 in the remaining part of August, 1869.

Ir on the Ist and 3 rd of September.

17 in the month of October.

16 on the 4 th and 6 th of November.

$2 \mathrm{I}$ on the nights of the 8 th, 9 th, and roth.

None on the I Ith in a watch at intervals from $7^{\mathrm{h}} 3 \mathrm{O}^{\mathrm{m}}$ till $\mathrm{r}^{\mathrm{h}} 3 \mathrm{O}^{\mathrm{m}}$

The nights of the 12 th and 13 th were thickly overcast. On the $14^{\text {th }}$ there was a break from $\mathrm{II}^{\mathrm{h}}$ to $12^{\mathrm{h}}$, but ro meteors seen; eight were observed on the night of the $15^{\text {th }}$, between $8^{\text {h }}$ and $13^{\mathrm{h}} 30^{\mathrm{m}}$, in bright moonlight. On the 28 th one was seen.

On December 29 a remarkable meteor, about equal to onefourth of the full moon, was seen through the window of the sitting-room, with a bright gas-light nearly between the observer and the window. Course from the Pleiades to the south horizon. None were observed in 1870 till March 30, when one was observed by Mr. Main at $8^{\mathrm{h}} 2 \mathrm{O}^{\mathrm{m}}$, larger than Jupiter, of a brilliant white, and a period of about 5 seconds from the zenith, vertically downwards a little to the south of the prime vertical.

On April I 2 th, at $I^{\text {h }} I^{\text {in }}$, one larger than a Lyra, of a brilliant white, visible $2^{\text {s }}$ to $3^{\text {s }}$ from a point near a Lyra, northward about $10^{\circ}$.

April 19 at $14^{\mathrm{h}}, 3$ in quick succession were seen near a Herculis, of about second magnitude, with a rapid downward motion, one nearly vertical, one slightly inclined to the west, and the other to the east. Watch in bright moonlight till $\mathrm{I}^{\mathrm{h}} 3 \mathrm{O}^{\mathrm{m}}$.

Only 7 were seen in May, and $I$ in June. On July 8 , at $9^{\text {h }}$ $2 \mathrm{O}^{\mathrm{in}}$, the sky completely overcast and no star visible, a meten was seen below the clouds at a point near Cassiopeia, with a downward motion of about $6^{\circ}$, and bursting at the end of two seconds of time.

Another meteor was seen below the clouds for about half a second on July 15 , at $12^{\mathrm{h}} 25^{\mathrm{m}}$, near $\beta$ Andromedx, scarcely any stars being visible in that part of the heavens.

A bout 20 were seen on the night of July 2 I by different persons while Mr. Luces was conversing with them, between $9^{\mathrm{h}}$ and $13^{\mathrm{h}}$, but he did not see any till $13^{\mathrm{h}} 43^{\mathrm{m}}$, when one equal to a Lyræ left a point near that star, taking its course, with a long train, towards the north horizon. 